$\begin{array}{ll} & \text { Etnográfica } \\ \text { etnográfica } & \text { Revista do Centro em Rede de Investigação em }\end{array}$

Antropologia

vol. $14(3) \mid 2010$

Vol. 14 (3)

\title{
Ghislaine Lydon, On Trans-Saharan Trails: Islamic Law, Trade Networks, and Cross-Cultural Exchange in Nineteenth Century Western Africa
}

\section{Francisco Freire}

\section{OpenEdition}

\section{Journals}

\section{Edição electrónica}

URL: https://journals.openedition.org/etnografica/238

DOI: 10.4000/etnografica.238

ISSN: 2182-2891

\section{Editora}

Centro em Rede de Investigação em Antropologia

Edição impressa

Data de publição: 1 outubro 2010

Paginação: 617-630

ISSN: 0873-6561

\section{Refêrencia eletrónica}

Francisco Freire, «Ghislaine Lydon, On Trans-Saharan Trails: Islamic Law, Trade Networks, and CrossCultural Exchange in Nineteenth Century Western Africa», Etnográfica [Online], vol. 14 (3) | 2010, posto online no dia 20 julho 2012, consultado o 11 fevereiro 2022. URL: http://journals.openedition.org/ etnografica/238; DOI: https://doi.org/10.4000/etnografica.238

Este documento foi criado de forma automática no dia 11 fevereiro 2022.

\section{(c) (1) \&}

Etnográfica is licensed under a Creative Commons Attribution-NonCommercial 4.0 International License. 


\title{
Ghislaine Lydon, On Trans-Saharan Trails: Islamic Law, Trade Networks, and Cross-Cultural Exchange in Nineteenth Century Western Africa
}

\author{
Francisco Freire
}

\section{REFERÊNCIA}

Ghislaine Lydon, On Trans-Saharan Trails: Islamic Law, Trade Networks, and Cross-Cultural Exchange in Nineteenth Century Western Africa, Nova Iorque, Cambridge University Press, 498 páginas. 2009

1 On Trans-Saharan Trails afirma, no título, trabalhar o contexto oeste-africano, parecendo contudo centrar-se na sua extensão oeste-sariana. Esta precisão bastará para sublinhar o carácter do texto: a complexidade do território trans-sariano, aqui considerado na sua medida mais ampla.

2 Esta obra insere-se num percurso historiográfico há muito trilhado, que nos remete precisamente para o tema do comércio trans-sariano. Face a esta tradição, parece ter-se estabelecido uma outra, antropológica, que é temática e conceptualmente distinta daquela, pesem embora os espaços permeáveis frequentados por ambas as disciplinas. Neste caso, uma "escola francesa" - ou mesmo bontiana - focada nos processos memoriais e nos mecanismos "internos" (tribais) de reprodução social tem marcado muita da mais recente produção antropológica dedicada à região. A história tem emprestado aos antropólogos um suporte material para dados de terreno pouco solidificados, e que a tradição oral insiste em contextualizar num arco temporal por vezes distendido até ao período almorávida (como ligação aos primórdios islâmicos da região, mas também como quadro filiatório). A antropologia aplicada a esta região parece, em larga medida, assente num quadro temático quase sempre circunscrito à 
"arabidade" e a tropos ainda herdados dos momentos colonial ou orientalista: Islão, tribo, parentesco, genealogia. Os trabalhos em história, por seu turno, parecem recorrer à antropologia de forma a suportar um contexto social (demasiado?) complexo, obviamente não circunscrito a uma linear progressão cronológica e, de facto, muito marcado pela oralidade.

3 A historiadora Ghislaine Lydon afronta directamente esta problemática, procurando uma interface válida entre materiais escritos e tradições orais (retomando outra questão clássica). Será precisamente este o mais importante contributo metodológico da obra, incorporando plenamente dados da tradição oral (mais de duzentas entrevistas) e arriscando defender a "centralidade da oralidade" neste trabalho (pp. 21-25). Muito embora seja este o argumento explicitado, este não será, de facto, o elemento central do texto. A "história oral" terá sido fundamental na reflexão que conduziu a autora ao longo de extensos períodos "no terreno", e a sua presença no texto é evidente, mas, no entanto, os seus argumentos continuam a basear-se privilegiadamente em fontes escritas. $O$ trabalho realizado sobre arquivos familiares, será, esse sim, o centro desta obra.

4 Ainda que as referências à literatura antropológica sejam quase nulas ao longo do texto, este trabalho poderá estabelecer-se como uma peça importante na negociação de novos espaços de reflexão entre história e antropologia. A "rede comercial do Oued Nun" constitui-se como o mais valioso exemplo desta abordagem, ultrapassando os limites da história económica na forma como conjuga os sentidos profundos do comércio transsariano com a cultura islâmica que impregna a região. Importa ainda assinalar a forma como a autora trabalhou "no terreno" sobre diversas escalas sarianas (Tishit e Guelmim, particularmente), aí realizando efectivamente "trabalho de antropólogo": procurando nova documentação em espólios familiares, entrevistando intervenientes directos no comércio caravaneiro (antigos caravaneiros e seus familiares) e actuais herdeiros de autoridades políticas, ou islâmicas, locais.

Assim, Lydon debate fontes orais e materiais escritos relacionados com o comércio trans-sariano, assente em informações alcançadas nos caravan hubs de Chinguetti, Ouadane, Oualata, Tishit e Guelmim. A autora expõe algumas peças recolhidas nos acervos privados de famílias ainda residentes nestes ksar-s (relatos de viagem, processos de herança, contabilidade, diversos documentos exarados por qadi-s e muftis), centrando finalmente a discussão no século XIX, um período historicamente "seguro" (porque melhor suportado, quer pelas fontes orais, quer pela documentação escrita). Exploram-se privilegiadamente os caminhos percorridos pelos tekna e pelos oulad bisbah (e secundariamente pelos kunta, tajakant e oulad d'laim), assinalando-se também a importância de comerciantes judeus ao longo desta rota. Os tekna, sediados em Guelmim, dirigiriam a maior parte destas operações, controlando habilmente uma autonomia face ao makhzen e dispondo de uma vasta rede de "agentes", de Essauira (no extremo norte desta rota) ao interior sariano (Tombucto, Tishit), e até à foz do rio Senegal. Já os oulad bisbah, também eles ligados a Guelmim, para além de uma reconhecida presença nos ksar-s de Tishit, Oudane ou Chinguetti, estender-se-iam ainda por toda a África Ocidental, com "agentes" em Rosso, São Luís do Senegal, Dakar, Louga, Banjul e mesmo Conakry (p. 196). Forma-se assim a "rede de Oued Nun".

6 A autora introduz (longamente) a história da região, acentuando a complexidade dos fluxos sociais e culturais desenvolvidos. Viaja-se através de um milénio de história, posicionando-se as bases da sua tese central: a profundidade das trocas culturais (cross 
cultural exchange) numa geografia extensa mas sempre interligada ("[Sahara] was never a barrier but always a bridge to intercontinental exchange, albeit one that required faith, resources, dexterity, and patience either to inhabit or to cross" [p. 105]). São então sistematizadas as referências históricas da região: a formação dos exércitos almorávidas e posterior conquista de um território entre o centro do actual Marrocos e a actual Mauritânia; a preponderância wangara na primeira metade do segundo milénio; a constante presença judaica; a conquista de Gao pelo exército marroquino em 1591.

7 Ao longo deste enquadramento, sinaliza-se o lento, mas sólido, processo de islamização (pp. 280-286) e o relevo do comércio de papel, responsável por duas profundas alterações: 1) a formação de uma paper economy (conceito tomado de Goitein), isto é, o desenvolvimento de um enquadramento documental dos processos comerciais; 2) a formação de uma paper economy of faith, isto é, uma ligação inegável entre a circulação de obras escritas e a expansão de um universo cultural islâmico (p. 337). Lydon socorrese - com mérito - do comércio de papel para defender a ligação entre fluxos mercantis e culturais. Os dados analisados promovem a centralidade de diferentes qadi-s e mufti-s na operacionalidade transcontinental desta rede comercial, à qual, claramente, não bastaria a ousadia dos seus agentes directos. $\mathrm{O}$ envolvimento islâmico das caravanas sarianas, e de todos os seus intérpretes, promove a interconectividade entre geografias aparentemente distintas, que se provam ancestralmente inter-relacionadas, quer em termos comerciais, quer, particularmente, enquanto espaços de partilha cultural.

Os contactos estabelecidos com comerciantes europeus parecem menosprezados neste trabalho, que, ainda que centrado no século XIX, se ocupa em expor longamente a história comercial da região. Este aspecto parece ser tratado com demasiada brevidade, sem que seja mencionado o alcance dos laços comerciais (e não só) criados ao longo de mais de cinco séculos de contactos permanentes ao longo da faixa atlântica a norte da foz do rio Senegal. Os limites cronológicos impostos pela autora definem um terreno analítico bem consolidado, e este défice de "comércio europeu" deve-se, julgo, à própria abordagem desenvolvida: a exploração privilegiada dos dados relativos à presença da cultura islâmica ao longo desta rota.

O texto mantém uma narrativa viva por entre temas bastante complexos (bibliograficamente bem ancorados, com recurso a fontes em árabe), apresentando sólidos argumentos quanto à profundidade dos vínculos estabelecidos ao longo do eixo ocidental das rotas caravaneiras trans-sarianas. Sem tratar, obviamente, um tema inovador, a autora supera as dificuldades colocadas a um terreno bem conhecido dos historiadores, ao qual acrescenta dados inovadores. 0 método seguido permite destacar uma rota comercial menosprezada, que aqui nos surge consolidada no fluxo de bens e saberes entre o Norte e o Ocidente africanos. On Trans-Saharan Trails é efectivamente um livro tecido por uma historiadora, mas que merece sem dúvida a atenção de antropólogos interessados nos contextos sarianos e oeste-africanos. 


\section{AUTORES}

FRANCISCO FREIRE

CRIA/FCSH-UNL 